Digital Press Social Sciences and Humanities

Technology 4.0 and Changes in Organizational Behavior in The Last Ten Years

Theda Renanita and Rahmat Hidayat

Proceeding of The 10th International Conference of Indigenous and Cultural

Psychology 2019

Kwartarini Wahyu Yuniarti, Donald H. Saklofske, Rosnah Ismail, Saadi Lahlou (eds) 


\title{
Technology 4.0 and Changes in Organizational Behavior in The Last Ten Years
}

\author{
Theda Renanita $^{1}$ \& Rahmat Hidayat $^{2}$ \\ 1 Faculty of Psychology, Universitas Ciputra \\ 2 Faculty of Psychology, Universitas Gadjah Mada \\ *e-mail: trenanita@gmail.com
}

\begin{abstract}
At present, the trend of technology usage is leading to the formation of a super-smart society, known as Technology 4.0. Technology 4.0 subsequently encourages the emergence of various innovations that in turn affect organizations. This article aims to provide stakeholders with an understanding of the current situation faced by organizations who are entering Technology 4.0. This literature review contains three parts, namely: a general illustration of Technology 4.0 in Indonesia along with a gap analysis between its application in Indonesia and the rest of the world; the factors that cause this aforementioned gap; and the changing elements of work and organizational life caused by Technology 4.0. The result of this literature review is expected to provide insights for the government, education institutions, the general society, and human resources who are working to enter the era of Technology 4.0.
\end{abstract}

\section{Keywords}

organizational change, organization, technology 4.0, work

\section{The History of Technology Development}

Human beings live in a world that is tightly connected to the use of technology. Technology has undergone continuous changes, known as the technological revolution (Cascio \& Montealegre, 2016), stated that there are three eras of the technological revolution. The three are the agricultural era, the industrial era, and the digital era. The agricultural era was characterized by the use of natural resources such as wind, land, livestock, and agricultural equipment. The industrial era was marked by the construction of factories, which contributed to mass production. Following the industrial era is the digital era, marked by the development of information and communication technology. In the digital era, digital resources can be accessed, processed, transferred, and stored anytime and anywhere. With the help of technology, work becomes better and faster.

In the era of technology 4.0, four technologies will be widely utilized by both organizations and the general society. The four technologies are the Internet of Things (IoT), artificial intelligence, robotics, and ledger technology.

Internet of Things (IoT) is a technology that allows people and objects to be connected anytime, anywhere, with anyone and anything through various networks and services (Jan Nolin \& Olson, 2016). Through IoT, objects that are interconnected, allowing them to be operated and detected using radiofrequency or RFID technology (Ashaton in Uden \& He, 2017). The use of IoT technology allows connectivity between people, people, and objects, as well as objects and other objects through the technology of the internet, cellular phones, Wi-Fi, and Bluetooth and communication technology.

Artificial intelligence (AI) is a system that can 'understand' the environment and subsequently take action in order to maximize specific opportunities/tasks. The system has abilities for inference, reasoning, learning from experience, planning, recognizing patterns, and epistemology (Bogue, 2017). This means that AI is a human-made system that has human-like intelligence and is able to engage in activities such as environment perception and decision making while also imitating the human cognitive processes.

Robots are agents that can interact with the physical world and can sense the world through sensors, build a coherent model of the world while also continuously renewing its model. Robots can make decisions and plan actions to carry out tasks (Sünderhauf et al., 2018). Robots are a form of artificial 
intelligence application and are equipped with sensors that allow it to recognize and interact with the real physical world.

Distributed ledger technology is a type of ledger technology that uses blockchains to increase efficiency and traceability of transactions (Keidanren Policy \& Action, 2018). Operationally speaking, distributed ledger technology refers to the use of digital-based transactions to enable recording of financial transactions such as transfers, deposits and money withdrawal, credit applications, international payments, as well as clearing which can then can be analyzed by anyone.

The use of technology 4.0 has brought significant changes in organizations. Through this article, the author will attempt to describe the application of technology 4.0 in the organization setting, as well as a gap analysis of its application, the factors that influence inequalities in its application, and what elements have changed in terms of work and organization life after its application.

\section{Technology 4.0: Application and Gap}

\subsection{Internet of Things (IoT)}

Internet of Things (IoT) allows people and objects to connect anytime, anywhere through any device by anyone (J Nolin \& Olson, 2016). According to the Commission of the European Communities (2009), IoT has several different abilities: namely: 1) Streamlining communication between devices; 2) Smart cars; 3) Communication between machines; 4) Smart building system (smart building); 5) Communication between objects and humans; 6) Communication between objects.

Meanwhile, IoT can be used in the following applications (Liu, 2018), 1) Smart product management; 2) Home automation; 3) Smart meters; 4) Continuous care; 5) Sustainable urban environment; 6) Waste management; 7) Smart transportation; 8) Intelligent shopping.

Several new businesses that use IoT in Indonesia have begun to emerge, such as Konekthing which is a smart home industry that allows residents to control their homes. Another industry is the development of products using automation such as businesses of automatic watering systems (Siramin), automatic fish machinery or e-fisheries, and smart garbage boxes (Ryza, 2016). Several large companies that use IoT are Toyota, DHL, BMW, Perusahaan Listrik Negara (PLN), and Badan Meteorologi, Klimatologi dan Geofisika (BMKG) (IoT Forum Indonesia, 2018). Indonesian state-owned companies such as PLN have collaborated with a telecommunication company called Telkomsel to apply the use of smart meters to produce more accurate checks and improve employee productivity (Haryanto, 2018). The use of the Integrated Operating Theater System (IOTS) will be more frequently used in Indonesia in the near future with RSUD Kota Semarang or Semarang State Hospital as the pioneer (Purbaya, 2016).

\subsection{Artificial Intelligence (AI)}

AI technology has a vital role in recognizing sounds, manipulating, navigating, machine vision, pattern recognition, location and mapping as well as more advanced $\mathrm{AI}$ abilities such as predicting the outcome of an action (Bogue, 2017). AI can also be used for machine learning, deep learning, reinforcement learning, data reading such as reading X-ray data (computer vision), language processing and enabling collaboration between systems and humans, compiling models of potential mismatches between machines and humans, as well as using algorithmic game theory and computational social choices (Hirsch, 2018).

Google is among one of the companies that have developed an AI that manages information from around the world, subsequently making data beneficial and easily accessible. AI can solve users, customers, and world problems (Dean, 2019). Amazon and Walmart have begun to utilize drones for shipping (Agarwal, 2018). AI is also used in employee selection processes through software that can filter candidates. Through AI, real-time communication can be carried out so that when a candidate is rejected, he or she can immediately find out and seek other job opportunities (Upadhyay \& Khandelwal, 2018). In the United States of America, AI is widely used in the health sector for instances such as detecting cancer and heart disease (Ho, 2018).

Of 112 companies in Indonesia that work in the line of IT businesses, 14\% have used AI. For instance, AI has become their core business strategy for Tokopedia, Go-Jek, and Grab. Tokopedia has started 
providing computer vision features which enable customers to upload photos of desired items to gain product recommendations from the platform (Winosa, 2019).

\subsection{Robotics}

A robot is a technology that has the ability to execute modern and automatic work (Fernandez, Gutierrez, Ruiza, Perez, \& Gil, 2012). In European countries such as in Germany, robotics is used to manage waste (Enway). In Greece, robotics is used in agriculture for automatic indoor gardening, controlled via an app (CityCrop). In the United Kingdom, the Factmata company uses a combination of robotics and AI to prevent the spread of hoax news. In the social field, robotics is used to treat older people (Ho, 2018). Similar to Europe, robotics in Asia has also been applied in the health sector, such as for diagnosing diseases in China (Peredoc) and caring for older people in Japan (Softbank robotics).

In Indonesia, robots are widely used in the automotive industry. For instance, at Mitsubishi, $40 \%$ of its activities utilize robots (Parwata, 2018). In the health sector, robots are used for surgery. A hospital that uses this technology is RS Bunda Jakarta (Prawira, 2014).

\subsection{Ledger Technology}

Blockchain technology has several abilities (Moyano \& Ross, 2017), such as the ability to:

1) Record financial activities that involve the bank verification processes which ease or facilitates the auditing and tracking process

2) Inter-system collaboration between financial institutions which enables anonymous document sharing

3) All institutions that employ ledger technology can verify consumers anonymously without violating regulations

4) System of cooperation between banks

Ledger technology offers extensive benefits related to data usage and storage. Some companies use ledger technology to manage data. For instance, British Airways uses ledger technology to manage flight data and passenger verification. Maersk uses ledger technology to track shipments of goods. Nestle uses blockchain technology to monitor production. Google improves cloud security services and protects data using ledger technology. Last but not least, AIA Group uses ledger technology for bancassurance (Goyal, 2018). In Indonesia, ledger technology is used in the financial sector, such as for online tax applications (Hirsch, 2018), and blockchain payment systems provided by BCA (Sulaiman, 2017).

Related to the application of technology 4.0 in other countries around the world, Indonesia seems to be lagging behind. IoT technology has been widely used in European countries. In Asia alone, IoT is growing rapidly in Japan and China. Even so, it does not mean that Indonesia has not implemented IoT. In Indonesia, IoT is slowly being used in the development of smart cities, home automation, smart meters, and continuous care.

With the invention of robots, AI has been widely used in the health sector. However, the use of AI in Indonesia's health sector is still limited. Several companies have emerged with new core businesses, such as Tokopedia and Go-Jek, which rely on computer vision. The use of computer vision makes it easy for consumers to find services that match their wants and needs. The percentage of companies in Indonesia that use AI is also quite high compared to other ASEAN countries such as Thailand, Singapore, and Malaysia. Based on the surveys conducted by analytical companies SAS and International Data Corporation (IDC), 24.6 percent of companies in Indonesia have adopted AI. Companies in Thailand took second place with 17.1 percent, followed by Singapore (9.9 percent), and Malaysia (8.1 percent).

Several companies in Indonesia have also used robots in company activities, though predominantly for automation. In other European or Asian countries, robotics is widely used in sectors of health, agriculture, and media. Meanwhile, companies that use robotics in Indonesia are mostly automotive companies.

Ledger technology is mostly used in the sector of finance and data cloud security. The use of ledger technology is dominated by developed countries such as Singapore, South Korea, Britain, United Arab Emirates, Kuwait, Japan, China, Canada, the Netherlands, and Switzerland (Terenzi, 2019). In Indonesia, the number of companies implementing blockchain technology is still relatively small, which subsequently leads to unestablished collaboration between systems and institutions. Also, the use of ledger technology is still limited to recognition. 


\section{The Potential of Technology 4.0 in Organizations}

Based on the previous explanation regarding technology 4.0, the doability of technology 4.0, and its application in Indonesia, there are several potential utilization of technology 4.0 in company contexts, particularly for human resources management. The following are a list of potentials of technologies 4.0:

\subsection{Internet of Things (IoT)}

At present, most companies have incorporated the use of the internet. This internet of things is the latest generation of the internet that connects humans with objects through sensors. There are many potential uses of IoT, such as:

1) Measuring and monitoring employee activities through sensors, which in turn enable companies to obtain input in the form of empirical data that can assist in creating an efficient work environment.

2) The use of IoT allows HR to create a flexible working space by managing work through mobile devices or other interconnected devices

3) The use of IoT allows HR to improve employees' health, done by regular health monitoring, which allows prevention measures to be taken when needed.

4) The use of IoT allows HR to track the mobility and activity of employees without causing them to feel burdened/pressured (Bhatia, 2018).

\subsection{Artificial Intelligence}

Artificial intelligence allows machines to think like humans (Biswas, 2019). There are two fundamental technologies used in AI, namely machine learning and deep learning. Machine learning is a branch of AI that allows machines to learn from and make predictions based on data. The primary key to using machine learning in the context of HR is:

1) Anomaly detection; to identify items, events or observations that do not match the dataset

2) Background verification; machine learning can be used to extract meaning and give a mark based on an applicant's resume data

3) Employee attrition; allows HR to find friction between employees thus efforts of prevention can be made

4) Personalization of content; provide a personal experience to employees through career path recommendations, professional development programs, or also by optimizing one's career based on previous applicants' data.

Meanwhile, deep learning is a branch of machine learning that makes it possible to study the data from the architecture of neural networks. Some examples of deep learning are image and video recognition, speech recognition, chatbots, and recommendation engines.

Some potential uses of AI are as follows:

1) Casting for employee candidates through social networks, for example through LinkedIn

2) AI can help filter candidates using their analytical skills. This screening process for candidates can be more objective because it does not involve emotions, an example of such application can be found in the following link https://ideal.com/

3) AI can serve as an "assistant" during the interview process of candidates; an example of such an application is Hireabby. More information can be found in the following link https://www.hireabby.ai/

4) AI can help administrative work such as payroll, employee performance data analysis, manage permits such as filing employee leave, or other repetitive jobs to be more efficient. An example of such an application is Textio.

5) AI can serve as HR's assistance in scheduling, providing reminders, personal searches, and others. Example: Google assistant, Siri, Alexa (Amazon)

\subsection{Robotics}

HR can use Robotics Process Automation (RPA) to take over repetitive operational tasks. The use of RPA can improve the accuracy and speed of data processing. RPA can also be used for payroll, provision of benefits, and reports on labor compliance both in manual or recurring activities (Zielinski, 2018). 


\subsection{Ledger Technology}

Currently, ledger technology is widely used in the financial sector. However, (Fincher, 2019) stated that ledger technology could also be used in Human Resources Management. First, ledger technology or blockchain technology can be used to protect data from cybercrime. The data here refer to matters like employees' data and companies' financial data (e.g., payroll, benefits, employee insurance). Second, blockchains can be used in employee recruitment processes as well as store employee data. Through this use, the recruiter can access the candidate's data, such as the data on their education, work experience, and recommendations. Third, Blockchains can present accurate data about time and attendance. This is very useful for calculating employee salaries based on their attendance.

\section{Factors that Influence The Gap in Technology Use}

1) Reluctance to adopt technology

Even though the rate of technology adoption in Indonesia is among the higher, the percentage of companies in Indonesia who do not plan to adopt AI within the next five years is also among the highest in Southeast Asia at 59\%. According to SAS Indonesia Country Manager Peter Sugiapranata, the percentage gap between the high adoption of technology and the absence plans to use AI in Indonesia shows that there are obstacles in regards to evolution from traditional business to digital business (CNN Indonesia, 2018).

2) The use of these four technologies requires immense costs

Despite the fact that technology improves employee quality, its implementation still requires a fee. These costs include the costs of using new technology coupled with research on the impact of using the new technology. By using new technology, it means that the company must employ new IT employees. Some companies are reluctant to hire new employees and choose to focus on maintaining the technology they have. Another cost is the cost of buying expensive software malware. With the use of new software, security is needed against virus attacks (Davenport, 2017).

3) Resistance to change

In this competitive era, using cutting-edge technology is a must. However, the use of new devices certainly causes changes, including changes in employee behavior. The presence of new technology can lead to disruption of employee behavior patterns. Changes that occur, such as changes in workload, create changes in work responsibilities, which may require new training. Such resistance can come from both employees and superiors (Delaney \& Robert, 2015).

\section{Elements of Work-Life and Organization that Have Changed with The Use of Technology 4.0}

Based on the application of technology and potential technology 4.0, the authors have identified two areas that have changed, namely companies' internal activities and relationships with external parties.

1) Internal company activities

a. The concept of work changes from what office-bound work to enabling work to be done anywhere. However, communication between one employee to another must continue to be maintained. As a result, collaboration is an important matter when executing company activities (Robertson, 2000).

b. Changes in the work pattern of HR. HR is reformed from human resource management to software-as-a-service. This means that HR work involves information technology that allows faster, more precise, and relevant results.

c. The focus of HR has shifted from cost savings to strategic business alignment, process improvement, and employee engagement (Micic \& Radosavac, 2018).

d. Big data-based corporate decision making (Herman, Herman, Mathews, \& Vosloo, 2018). Through technology, HR can quickly and accurately acquire big data. Big data is used to add insight into all levels of an organization (top management, middle-level management, 
administrative level, and operational level), which subsequently leads to better decision making at various levels.

2) Companies' relation with external parties (consumers/other companies)

Connectivity promotes collaboration with other companies (Pagani \& Pardo, 2017). There are three types of company digitalization, namely an activity-links-centered, a resource-ties-centered, and an actorbonds-centered type of digitalization. An activity-links-centered digitalization occurs when the company connects company activities with existing technology. Instead of making new company activities, existing activities are optimized; for example, the use of technology at Biomérieux to facilitate B2B tracking. A resource-ties-centered type of digitalization occurs if the company carries out activities that in turn, creates new company activities. An example of this type of digitalization is the cooperation between IBM and Dassault Systems to create a digital diagnostic tool. An actor-bonds-centered type of digitalization occurs if there is inter-company coordination for transaction costs. These activities involve connectivity and recombination, such as in marketplaces.

\section{Conclusion and Recommendation}

\subsection{Conclusion}

This study provides an overview of the development of technology 4.0 both in Indonesia and in the world. It seems that the development of technology 4.0 in Indonesia is still lagging behind other countries, especially Western countries.

The use of technology 4.0 in Indonesian companies is not yet widespread/exhaustive. Implementation of technology 4.0 is mostly limited to large companies. Meanwhile, traditional companies still seem to have trouble catching up. The use of technology 4.0 is also still limited to certain sectors, such as automotive, health, and banking sectors. There are still many potential uses of technology 4.0 in the field of HR, such as application in payroll systems, recruitment and selection systems, automation of company activities, and data security maintenance.

The use of technology results in several changes in the organization. For organizations that are conducting digitalization, organizations must be able to anticipate internal changes or change related to the organization's external relations.

\subsection{Recommendation}

The use of new technology also involves obstacles such as society's reluctance to use new technology, substantial costs, and resistance to change. As a recommendation, HR must address the following gaps of technology application: the need for a payroll system, recruitment and selection system, automation of company activities, and data security maintenance. Companies can use the services of HR consultants as an alternative to managing labor without having to adopt new technology immediately. For the government, it is important to compile a curriculum that is based on the competence of graduates who have the skills to use technology. Current HR staff is recommended to improve self-skills in technology use as technology is an essential instrument that supports HR activities.

\section{References}

Agarwal, R. (2018). 10 Examples of Artificial Intelligence You're Using in Daily Life. Retrieved May 15, 2019, from https://beebom.com/examples-of-artificial-intelligence/

Bhatia, G. (2018). How Internet of Things (IOT) Will Impact HR? Retrieved May 15, 2019, from https://empxtrack.com/blog/how-internet-of-things-will-impact-human-resources/

Biswas, S. (2019). The Beginner's Guide to AI in HR. Retrieved May 15, 2019, from https://www.hrtechnologist.com/articles/digital-transformation/the-beginners-guide-to-ai-in-hr/ 
Bogue, R. (2017). The Role of Artificial Intelligence in Robotics. Industrial Robot: An International Journal, 41(2), 119-123. Retrieved from https://doi.org/10.1108/IR-01-2014-0300

Cascio, W. F., \& Montealegre, R. (2016). How Technology Is Changing Work and Organizations. Annual Review of Organizational Psychology and Organizational Behavior, 3, 349-375. Retrieved from https://doi.org/10.1146/annurev-orgpsych-041015-062352

CNN Indonesia. (2018). Aplikasi Online Pajak Gunakan Teknologi Blockchain. Retrieved from https:/www.cnnindonesia.com/ekonomi/20180427152840-532-294148/aplikasi-onlinepajak-gunakanteknologi-blockchain

Commision of The European Communities. Internet of Things -- An Action Plan for Europe, Europe (No. COM (2009) 278 final), Commision of The European Communities, Brussels. , (2009).

Davenport, D. (2017). Five Reasons Why The Cost of Technology Is on The Rise. Retrieved May 15, 2019, from http://insights.motherg.com/blog/five-reasons-why-the-cost-of-technology-is-on-the-rise

Dean, J. (2019). Bringing The Benefits of AI to Everyone. Retrieved May 15, 2019, from https://ai.google/about/

Delaney, R., \& Robert, D. (2015). The Challenge of Integrating New Technology into An Organization. Mathematics and Computer Science Capstones, 25.

Fernandez, G. C., Gutierrez, S. M., Ruiza, E. S., Perez, F. M., \& Gil, M. C. (2012). Robotics, The New Industrial Revolution. IEEE Technology and Society Magazine, (June), 31(2), 51-58.

Fincher, M. (2019). 5 Ways Blockchain Technology Can Revolutionize Human Resource Management. Retrieved from https:/www.hrtechnologist.com/articles/safety/5-ways-blockchain-technology-canrevolutionize-human-resource-management/

Goyal, S. (2018). 20 Enterprises Which Are Implementing Blockchain Technology. Retrieved May 15, 2019, from https://101blockchains.com/enterprises-implementing-blockchain/

Haryanto, A. T. (2018). Telkomsel-PLN Implementasikan Layanan Smart Meter Berbasis NB-Iot. Retrieved May 15, 2019, from https://inet.detik.com/business/d-4280564/telkomsel-pln-implementasikan-layanansmart-meter-berbasis-nb-iot

Herman, J., Herman, H., Mathews, M. J., \& Vosloo, J. C. (2018). Using Big Data for Insights into Sustainable Energy Consumption in Industrial and Mining Sectors. Journal of Cleaner Production, 197(1), 13521364. Retrieved from https://doi.org/10.1016/j.jclepro.2018.06.290

Hirsch, P. B. (2018). Tie Me to The Mast : Artificial Intelligence \& Reputation Risk Management. Journal of Business Strategy, 39(1), 61-64. Retrieved from https://doi.org/10.1108/JBS-11-2017-0160

Ho, J. (2018). The Companies Using Robotics and AI to Make Lives Better: Americas. Retrieved May 15, 2019, from https://www.distrelec.de/current/en/robotics/the-companies-using-robotics-and-ai-to-make-livesbetter-americas/

Keidanren Policy \& Action. (2018). Society 5.0 : Co-Creating The Future. Retrieved May 15, 2019, from http://www.keidanren.or.jp/en/policy/2018/095.html

Liu, L. (2018). Iot and A Sustainable City. Energy Procedia, 153, 342-346. Retrieved from https://doi.org/10.1016/j.egypro.2018.10.080

Micic, L., \& Radosavac, V. (2018). Influence of Information Technology to Human Resources Management: Key Trends in 21st Century. Advanced Technologies, Systems, and Applications II, 28. Retrieved from https://doi.org/https://doi.org/10.1007/978-3-319-71321-2_25

Moyano, P., \& Ross, O. (2017). KYC Optimization Using Distributed Ledger Technology. Business \& 
Information Systems Engineering, 59(6), 411-423. Retrieved from https://doi.org/10.1007/s12599-0170504-2

Nolin, J, \& Olson, N. (2016). The Internet of Things and Convenience. Internet Research, 26(2), 360-376. Retrieved from https://doi.org/https://doi.org/10.1108/IntR-03-2014-0082

Nolin, Jan, \& Olson, N. (2016). The internet of things and convenience. Internet Research, 26(2), 360-376. https://doi.org/https://doi.org/10.1108/IntR-03-2014-0082

Pagani, M., \& Pardo, C. (2017). The Impact of Digital Technology on Relationships in A Business Network. Industrial Marketing Management, 67, 185-192. Retrieved from https://doi.org/10.1016/j.indmarman.2017.08.009

Parwata. (2018). Robot Kuasai 40 Persen Pekerjaan Manusia di Pabrik Mitsubishi Cikarang. Retrieved May 15, 2019, from https://otomotifnet.gridoto.com/read/231152157/robot-kuasai-40-persen-pekerjaan-manusiadi-pabrik-mitsubishi-cikarang

Prawira, A. E. . (2014. (2014). Bedah Robotic di RS Bunda Jakarta lebih murah. Retrieved May 15, 2019, from https://www.liputan6.com/health/read/2141583/bedah-robotik-di-rs-bunda-jakarta-lebih-murah

Purbaya, A. A. (2016). Punya Teknologi RS Canggih Semarang Harap Bisa Jadi Tujuan Penangan Medis. Retrieved May 15, 2019, from https://health.detik.com/berita-detikhealth/d-3284848/punya-teknologi-rscanggih-semarang-harap-bisa-jadi-tujuan-penanganan-medis

Robertson, K. (2000). Work Transformation: Integrating People, Space and Technology. Facilities, 18, 376382.

Ryza, P. (2016). Siramin dan Visi Mengubah Wajah Pertanian Indonesia dengan Teknologi. Retrieved May 15, 2019, from https://dailysocial.id/post/siramin-dan-visi-mengubah-wajah-pertanian-indonesia-denganteknologi

Sulaiman, F. (2017). BCA Kita Sudah Kembangkan Teknologi Blockchain. Retrieved May 15, 2019, from https:/www.wartaekonomi.co.id/read163962/bca-kita-sudah-kembangkan-teknologi-blockchain.html

Sünderhauf, N., Brock, O., Scheirer, W., Hadsell, R., Fox, D., Leitner, J., \& Corke, P. (2018). The Limits and Potentials of Deep Learning for Robotics. The International Journal of Robotics Research, 37(4-5), 405420. Retrieved from https://doi.org/10.1177/0278364918770733

Terenzi, C. (2019). 11 Countries Working With Blockchain Technology. Retrieved May 15, 2019, from https://usethebitcoin.com/11-countries-working-with-blockchain-technology/

Uden, L., \& He, W. (2017). How The Internet of Things Can Help Knowledge Management : A Case Study From The Automotive Domain. Journal of Knowledge Management, 21(1), 57-70. Retrieved from https://doi.org/10.1108/JKM-07-2015-0291

Upadhyay, A. K., \& Khandelwal, K. (2018). Applying Artificial Intelligence: Implications for Recruitment. Strategic HR Review, 17(5), 255-258. Retrieved from https://doi.org/10.1108/SHR-07-2018-0051

Winosa, Y. (2019). 14\% Perusahaan Indonesia Gunakan AI sebagai Core Business Strategy.

Zielinski, D. (2018). Robotic Process Automation Gains A Foothold in HR. Retrieved May 15, 2019, from https://www.shrm.org/resourcesandtools/hr-topics/technology/pages/robotic-process-automation-hr.aspx 